\section{Huxley remembered}

Sir Julian Huxley, FRS, one of the best known scientific personalities of our day, died in London on February 14 at the age of 87 .

Huxley was a King's Scholar at Eton and went on to Balliol, Oxford, where he became Brackenbury Scholar and, from 1910-12, a lecturer in zoology. As a undergraduate, he was also awarded the Newdigate Prize for Poetry. At 25, he became Professor of Zoology at the Rice Institute in Houston, but at the outbreak of war returned home and joined the Army Intelligence Corps, serving at the Italian front when the armistice was signed. He returned to Oxford in 1919 as a Fellow of New College and Senior Demonstrator in Zoology, and in 1925 was appointed Professor of Zoology at King's College, London. He also held the office of Fullerian Professor of Physiology at the Royal Institution from 1926-28, but resigned both scientific posts to devote more time to writing and research. His association with the Zoological Society of London as Secretary began in 1935 and lasted until 1942, during which time he helped to develop Whipsnade Zoo. His lifelong interest in Africa resulted in his being a member of the committee of Lord Hailey's 'African Survey' from 1933-38, and a member of the 1944 Committee on Higher Education in West Africa.

Because of his experience and powerful interest in the problems of social evolution and education, the British government persuaded him to become the first Director-General of UNESCO in 1946.

His many publications on animal behaviour, evolution and genetics are too numerous to mention. His Problems of Relative Growth (1932) was a turning point in the study of differential growth of parts of the body, and Evolution, the Modern Synthesis (1948) remains the most comprehensive modern work on this subject. But beguiled audiences of the BBC's 'Brains Trust' programme will remember him best as one of the original panellists, and particularly during the Second World War. Huxley also lent his support to many other institutions-the British Humanist Association, the Family Planning Association, the Nature Conservancy, and so on.

Recognition of his work came from all sectors. Among many were the Kalinga Prize (1953) for popular science writing, the Darwin Medal of the Royal Society (1957) for contributions to the study of evolution, and a Knighthood in 1958.

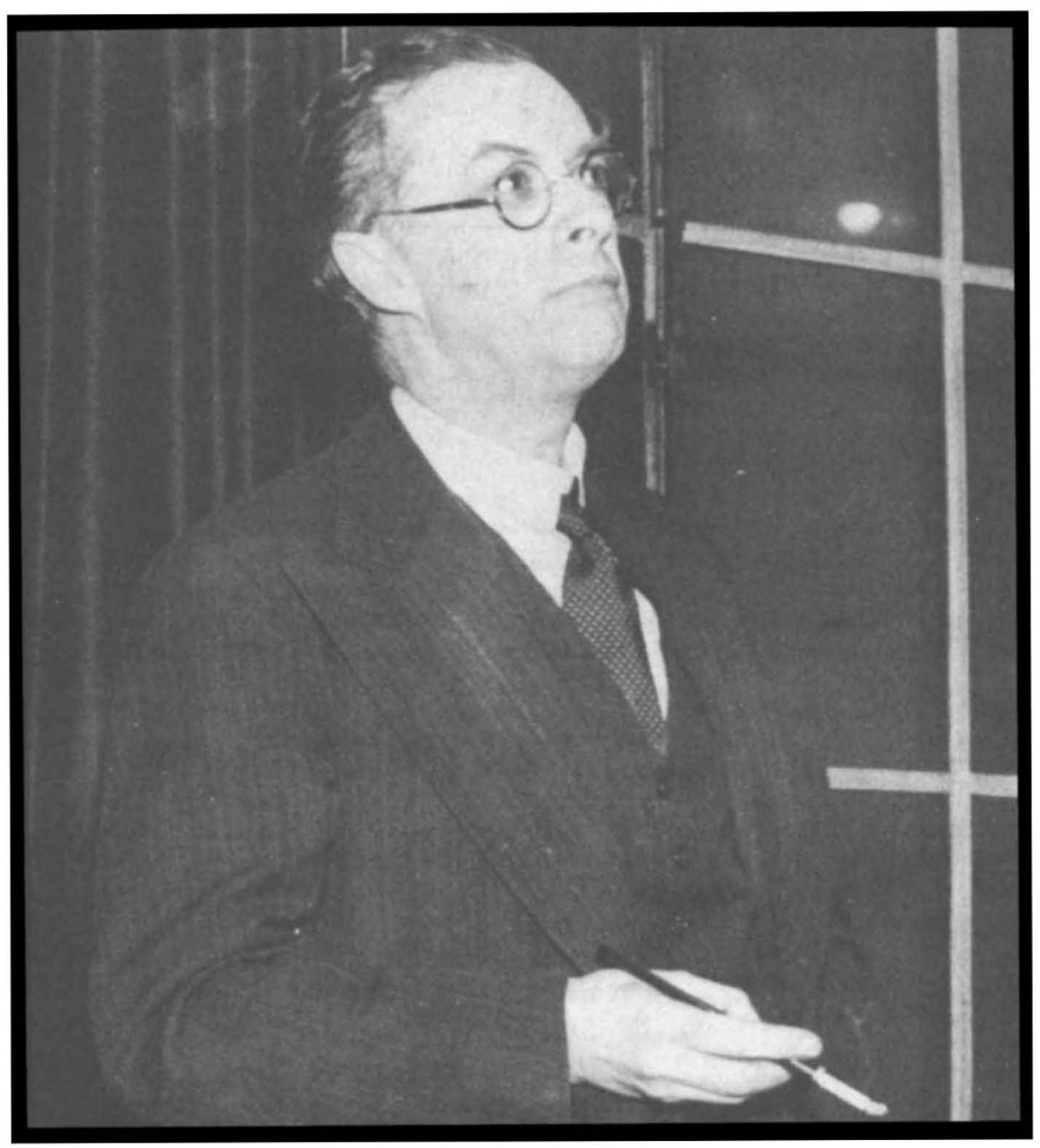

Julian HuXley was only a decade or so older, but he was one of my 'heroes' from the time (1921) when I was starting research in chemical embryology. I never knew him really well and never spent very much time with him, but he was always there as a kind of leading figure "amidst the encircling gloom"; and occasionally our lives impinged strongly on each other. In the 1920 s he was perhaps best known for his work at Oxford on the hybrid control of amphibian metamorphosis. This was outside my field, as I never worked in classical endocrinology, but when the 1930 s came I was extremely interested iri Julian's book on heterogony (or heterauxesis, as it afterwards came to be called) Problems of Relative Growth. Together with Georges Teissier in France I spent a good deal of time in applying these conceptions to the relative growth of the chemical constituents of animal bodies. This turned out to be one of those lines of of investigation which, though interesting in themselves, do not lead immediately to anything further. Quite different was the situation with Julian's Elements of Experimental Embryology, which he wrote with G.R. de Beer in 1934. This was at the beginning of the story of embryonic induction; based on the fundamental experiments of Spemann and his collaborators, it set the stage for a vast amount of work on the 'morphogenetic hormones'. Terminologies change, and organisers tcday might be called 'semantophore macro-molecules', but although such great advances have been made in the study of the hereditary 'books of instructions', the nucleic acid chains, it seems that still today it has not been possible to identify the molecules which pass from cell to cell and determine spacific differentiation destinies. Doubtless messenger RNA is in the picture somewhere. In any case Huxley and de Beer was a stirring overture to a field of experimental morphology still of the highest importance and fascination today.

But neither Julian Huxley nor I were spirits circumscribed by the walls of the laboratory. Both of us were interested in philosophy, religion, artistic creation, history and literature; both of us, like Charles Sherrington and many other scientists, were moved to write poems from time to time. We must retrace our steps, for Religion without Revelation came out in 1927: while my Sceptical Biologist was 1929 of course our standpoints were rather different, though both in a way syn- 
cretistic. Julian upheld the family tradition of agnosticism and what came to be called 'humanism', while I was for accepting the practice of all the forms of human experience while not granting absolute validity to any of them. Consequently I retained liturgical religion and was content to be described as a left-wing Christian socialist --but all this never came between us, and on a great many matters we saw closely eye to eye. It was rather like an experience I once had with Fred Hoyle. The Cambridge Union proposed to debate that "wherever science advances religion recedes", and he was to be the proposer, while I was cast as the opponent. So we had tea together, and concluded, after carefully looking into it, that there was just that hair's breadth of difference between us as to make the affair possible. It was rather like that with Julian and me.

But politics kept on breaking in. Over a couple of decades, centering on the 1930s, the "Younger Scientists" became a label as political as the "Young Turks" had been in an earlier time. Here the essential crux was the relations of science and society; what really were they in the liberal democratic, bourgeois, capitalist society that we all knew, what had they been in the societies of the long-past world, and what could they be imagined to be in socialist society, whether nascent as at that time in the USSR, or more ideally foreseeable in future socialist societies? This movement of the 1930 s was the lineal ancestor of such bodies as the British Society for Social Responsibility in Science today; with the big difference that present leading men, such as Joseph Rotblat and Stephen Rose, are contending with a world of nuclear power and nuclear weapons in which the problems of pollution have come much more into the foreground than they were in the $1930 \mathrm{~s}$. But in those days you had a very powerful group, of which perhaps Julian Huxley and J. B. S. Haldane were the oldest, including Conrad Waddington, Desmond Bernal, Lancelot Hogben, Dorothy Crowfoot and Hymen Levy. Other scientists were radical, though not on the left, such as Cyril Darlington and John Baker, while others yet again, like Patrick Blackett and Solly Zuckerman, so phrased their sociological beliefs as not to lose touch with the "corridors of power' and the establishment, thus retaining a chance of influencing national policy. All these 'elements', quorum pars minimus fui, met together from time to time in the "Quots and Tots", a dining club in London which was only extinguished by the Second World War. Needless to say, it took its name from the phrase quot homines tot sententiae, but in fact throughout the 1930s there was a real consensus of agreement among the "Younger Scientists". Their pronunciamientos constantly enraged the older generation entrenched in Burlington House, where so strong was the prejudice against scientists doing anything other than science, that I was reduced (though I do not think Julian ever was) to adopting a pseudonym for some of my extra-scientific writings. Some may remember that in allusion to certain extremely distinguished officers of the Royal Society, the "Younger Scientists" were accused of riding roughshod over hill and dale.

Subjects like animal behaviour and bird-watching were always closed books to me, a side of Julian that I never knew. Our orbits came into the closest conjunction, however, after the foundation of UNESCO in 1946. I always thought it was Ellen Wilkinson, not R. A. Butler as has recently been said, who nominated Julian Huxley as the first Director-General; at any rate I was far away in China at the time. I had been one of those who throughout the last years of the war had made great agitation to get science included with education and culture in this new specialised agency of the United Nations. And it was therefore the greatest of pleasures to get a cable from Julian (I forget whether it was in Chungking or Nanking) asking me to return at once to head up the Natural Sciences Division. I duly came, we established ourselves in a large, gaunt, empty house of ambassadorial character in Belgrave Square, and the recruitment of staff went merrily on. The UNESCO years brought me into very close touch with Julian and that was the time I got to know him best. In those days UNESCO officials were rot bound down by too much red tape, as happened later; for example when the Naples Marine Biological Station was about to close down, as its seawater pumps had worn out, a couple of telephone calls with Stafford Cripps elicited that there were plenty of American surplus pumps on the quayside in that very city, and these could be used to keep things going. Or again, as soon as we knew that the Poles had lost, during the war, all their printing machines capable of setting up mathematical equations, Julian and I by a couple of telephone calls could get some new machines moving on their way to Warsaw.

The UNESCO period, fortunately, found Julian Huxley in one of his periods of most frenetic energy and activity. Our daily conferences were unforgettable, with André Thomas Thomas for culture, and Kuo Yu-Shou for education. Dear Dr Kuo, I had known him a long time before when he was Commissioner of Education in
Szechuan Province. Those were the days when we formulated between us many a policy for which afterwards, indeed for the rest of his life, Julian Huxley did great propaganda workthe liquidation of illiteracy, the control of population increases, and the reproduction of great classical spiritual books in many languages other than trose in which they were originally written. Some of these enterprises have prospered remarkably through the years-for example the international understanding inculcated by the UNESCO Courier, which appears all over the world in many languages; or again the UNESCO History of the World. Julian used to maintain that this was originally my idea, but I feel quite certain that it was his, and all I did was to back it up through thick and thin at various meetings, including those of the Executive composed of the delegates of all the member states. This work in many volumes must now be in school libraries all over the world and really may be said to be fairly free from nationalistic prejudices. Thomas, Kuo and I were very close to Julian, and only Thomas carried on for any length of time after the first change of Director-General. Besides, there were not only the meetings but also very companionable walks and meals on Sundays in the forests of Fontainbleau and Rambouillet where we could compare notes ad lib.

Finally, in a last act, as it were, Julian and I enormously enjoyed investigating Amerindian archaeology on the occasion of the Second General Conference of UNESCO in Mexico City. Together we scoured the wonderful National Museum, visited unforgettable sites, like Teotihuacan, Xochicalco and Chichen-Itza; and sat at the feet of Mexican scholars and writers like Alfonso Caso, Miguel Covarrubias and Alberto RuzLhuillier. All this bore much fruit for me later on when in the fourth volume of Science and Civilisation in China I had to face the problem of preColumbian culture contacts across the Pacific from East Asia.

Julian Huxley was a man for whom nothing human was foreign; one thought naturally of the phrase nihi humanum me alienum puto. $\mathrm{He}$ was blessed beyond measure by his marriage with Juliette, happy essentially from beginning to end, right from the day when her father's vignerons took Julian to be Oexle-le type qui a inventé les dégrés. All their friends think of her with the deepest affection, and hope that knowledge of this may moderate, even in however small a way, the sense of loss from which she, like us, is assuredly suffering.

Joseph Needham 